\title{
Creativity Level in Chemistry Education by Gender Among Secondary School Students in Kenya
}

\author{
Florence Kamonjo $^{1 *} \quad$ Samuel Wachanga ${ }^{2}$ \\ 1 School of Education, University of Kabianga, P.O Box 2030-20200. Kericho, Kenya \\ 2 Faculty of Education, Egerton University, Kenya P.O Box 536-20100. NJoro Kenya
}

\section{The research is financed by Kenya government}

\section{Abstract}

Education is the most critical ingredient in a country's development process in the social, economic and political realms. Kenya in its vision 2030 hopes to be transformed into a newly industrialised, middle-income country providing a high quality of life to all its citizens in a clean and secure environment by the year 2030.To realise this vision, the country needs to develop through its education system, manpower that is trained to think creatively. The role of Chemistry in the development of the scientific base of a country cannot be over emphasized and Kenya is no exception. Kenya's secondary school Chemistry, Physics and Biology syllabi recommend the acquisition of creative skills by students. Few studies have been carried out in Kenya with regard to scientific creativity in secondary schools. Studies in Physics and Biology have shown that the level of scientific creativity is low and is influenced by such factors as gender and knowledge. It is not clear whether the low levels on scientific creativity found in Biology and Physics also apply to Chemistry hence there is need to determine the level of scientific creativity in Chemistry and factors influencing the level. Therefore, the purpose of this study was to determine the level of scientific creativity in Chemistry education in Kenya. The study went ahead to find out whether there are gender differences in scientific creativity in chemistry as a whole and in the different aspects of scientific creativity namely; sensitivity to a problem, flexibility, recognition of relationships and planning for investigation. The study involved ex-post facto research with causal-comparative and correlational designs. The population of the study was all Form Three students in National Secondary Schools in Nairobi and Kiambu Counties and all Form Three students in District Secondary Schools in Muranga and Kajiado Counties in Kenya. A sample of 16 schools (4 Boys' and 4 Girls' National schools and 4 Boys' and 4 Girls' District schools) were involved in this study. National schools were selected through random sampling, while the County schools selection were through purposive random sampling. Participating Form Three stream (class) in the schools were selected through stratified random sampling. A total of 672 students, (275 boys and 397 girls) were involved in the study. Data were collected using the Chemistry Scientific Creativity Test (CSCT) instrument. Quantitative data from CSCQ was analysed using t-test. Chi-square was used to test for the relation between the two variables; gender and scientific creativity in Chemistry. Tests of significance were done at 0.05 alpha level. The findings of this study indicated that the level of scientific creativity in chemistry education is low. The findings further indicated that the level of scientific creativity in Chemistry was not gender dependent.

Keywords: Chemistry, Science, Creativity, Gender

DOI: $10.7176 / \mathrm{JEP} / 10-20-07$

Publication date:July $31^{\text {st }} 2019$

\subsection{Introduction}

Chemistry is a branch of science that studies the composition and properties of matter and the changes it undergoes. Chemistry is far more than a collection of facts and a body of knowledge. It's all about matter, which is anything that has mass and occupies space. Chemistry is sometimes called the central science because it bridges other natural sciences, including Physics, Geology and Biology. According to Jegede (2007), it is a core subject for medical science, textile science, printing technology and chemical technology. Therefore, the essence of appropriate conception of concepts related to Chemistry is of a very great significance because the subject is very important to science and technology. (Okere, 1996) cites it is an important subject in choice of career in university.

The concept of creativity has proven over the years to be an elusive one to define. As early as 1960, Repucci (cited by Welsch, 1981) counted between 50 and 60 definitions in the literature on creativity. Twenty years later, an extensive review forced Welsch (1981) to conclude that the literature contains such a variance of definitional statements that the task of arriving at an integrated and agreed definition is virtually impossible. Analysis of these definitions suggests that creativity consists of at least four components: (1) the creative process, (2) the creative product, (3) the creative person, and (4) the creative situation (MacKinnon, 1970; Mooney, 1963).

More recently different kinds of creativity have been identified, (Creative Economy Report, 2008), as follows:

- Cultural (artistic) creativity involves imagination and a capacity to generate original ideas and novel ways of interpreting the world, expressed in text, sound and image;

- Scientific creativity involves curiosity and a willingness to experiment and make new connections in problem 
solving;

- Economic creativity is a dynamic process leading towards innovation in technology, business practices, marketing, etc., and is closely linked to gaining competitive advantages in the economy.

All of the above involve technological creativity to a greater or lesser extent and are interrelated, as shown in Figure 1 (Creative Economy Report, 2008, Economy of Culture in Europe, 2006).

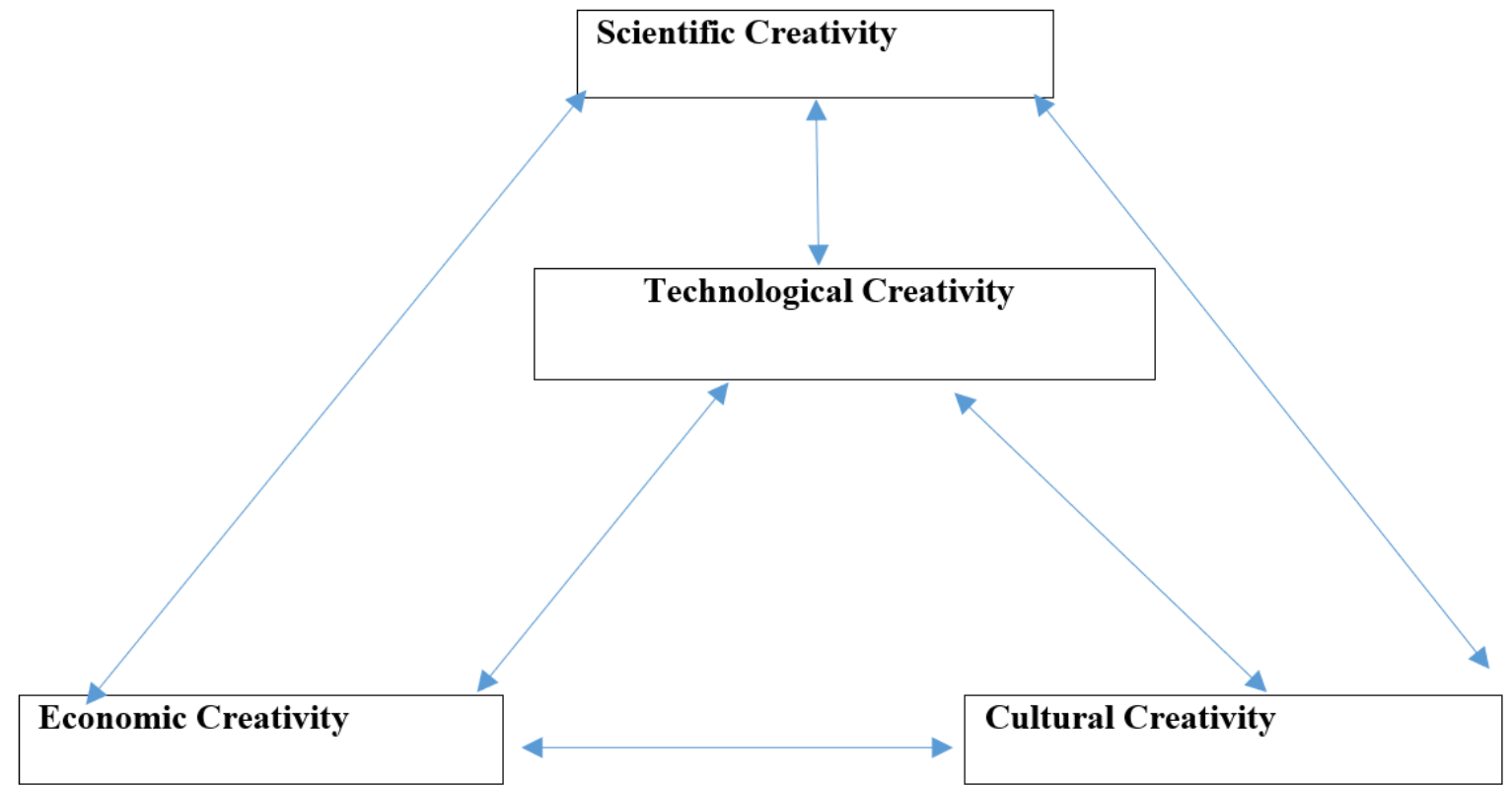

Figure 1. Relations between Creativities (source: Economy of Culture in Europe, 2006)

According to Hu and Adey (2002), scientific creativity is a kind of intellectual trait or ability producing or potentially producing a certain product that is original and has social or personal value, designed with a certain purpose in mind, using given information.

It is generally accepted that creativity is an important aspect of scientific ability. Problem solving, hypothesis generation, experimental design and technical innovation all require a particular form of creativity peculiar to science. Alexander (1992) and Amabile (1987) have shown that all creativity has a domain specific component and so there is a need to distinguish scientific creativity from creativity in general.

Two approaches have been suggested to scientific creativity namely;

- Psychometric approach

- Cognitive approach

The psychometric approach to measuring scientific creativity by Guilford (1950), during the peak era for psychometric research, introduced 'divergent thinking' as a key concept to describe the creative process. He suggested that creativity could be measured with paper and pencil tests. In so doing, he laid the foundation for a major change in creativity research (Sternberg \& O'Hara, 1999). Guilford test enabled creativity to be understood as an intellectual ability, and he developed a test instrument that researchers could use to study this ability in a variety of situations and contexts. Today, psychometrics have lost dominance and cognitive processes are studied in new and more varied ways, but Guilford's concept of divergent thinking and his creativity tests remain. Guilford (1967) describes divergent thinking as thinking in various directions in order to arrive at alternative solutions to a problem. Among the abilities relating to divergent thinking are: fluency, the ability to produce many solutions/ideas to a problem; flexibility, the ability to generate different types of solutions/ideas; and originality, the ability to generate rare and uncommon solution/ideas.

A three dimensional model of scientific creativity was developed in Kings College, London (Hu and Adey, 2002). The three-dimensional Scientific Structure Creativity Model (SSCM) consists of three dimensions; Personal Traits, Process and Scientific Product.

Personal Trait: This is the first dimension of (SSCM) consisting of;

Fluency which means the number of original ideas produced, flexibility which is the ability to 'change tack', not to be bound by an established approach after that approach is found no longer to work efficiently and originality which is interpreted statistically as an answer which is rare or an answer that occurs only occasionally in a given population, is considered original.

Fluency, flexibility, and originality thus form one dimension of the model, one which can be described as being a personality trait, the characteristics of the creative person.

Product (Scientific Products): This is the second dimension of SSCM consisting of; technical products, 
advances in scientific knowledge, understanding of scientific phenomena, and scientific problem solving (sensitivity to science problem).

The Process: This is the third dimension of SSCM consisting of the process an individual undergoes in the process of being creative. This suggests a distinction between creative imagination and creative thinking.

The three-dimensional Scientific Structure Creativity Model SSCM which arises from this analysis is shown in Figure 2. The proposed structure is designed as a theoretical foundation on which the measurement of scientific creativity and the cultivation of scientific creativity may be based.

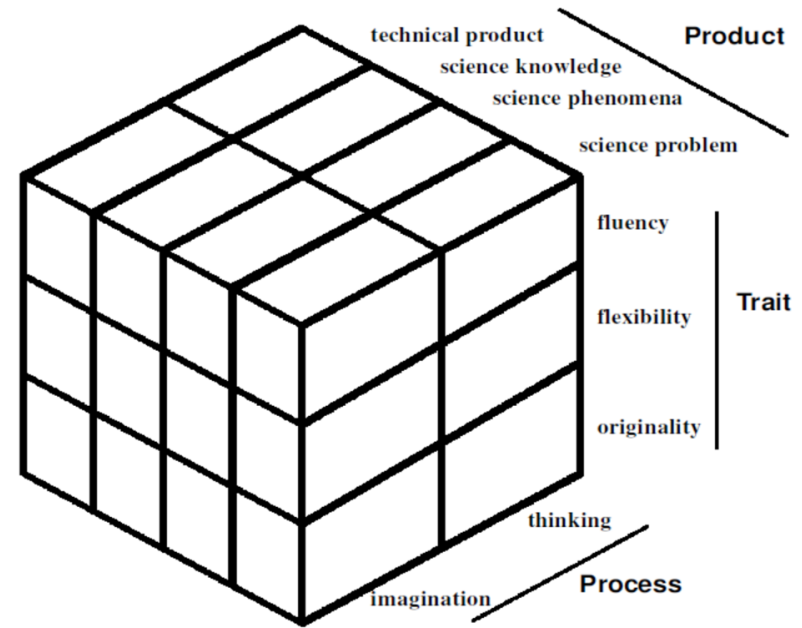

Figure 2: Scientific structure creativity model (Hu \& Adey, 2002)

The Cognitive approach seek to understand the mental processes underlying creative reasoning rather than just identifying particular intellectual skills (Sternberg \& Lubart, 1999). Creative reasoning can be traced back to a fundamental set of common generative processes. These include recalling structures from memory; the formation of associations among structures; mental synthesis of new structures; mental transformation of existing structures into new forms; and analogical transfer of information from one domain to another. These processes also account for thinking in extremely creative people, who exhibit enhanced intensity of application of the processes; greater richness or flexibility of stored cognitive structures to which the processes are applied, and higher memory capacity. Sternberg \& Lubart, (1999); Ryhammar \& Brolin, (1999) have suggested several models and theories to explain how such 'ordinary' cognitive processes can work together in creative reasoning.

According to (Curriculum Development Centre 2001), Curriculum Development Council, 2002) of Malaysia and Hong Kong respectively, science subjects are seen as one of the important subjects in the development of creativity. Cultivating creativity in science learning started long time ago and as early as the 1980 's, Mc Comark and Yager (1989) proposed a taxonomy of science education which includes the domain of imagination and invention. Based on these taxonomies, Gilbert (1992) suggests six questions in the learning design. Question forms are integration, imagination, brainstorming, organizing, making analogies and metaphors and conceptualization. Cultivating creativity in science learning can be done by use of a variety of other strategies, one of them being use of science instruction, which is based on scientific method process in creative thinking (Aksoy (2005). Use of such methods has increased the creative thinking level of the students, has improved their academic success level and has advanced their attitudes to the lesson of science knowledge (Aksoy 2005). Adzliana, Jizah, Punia, \& Kamisah (2012) suggested that there are five types of nurturing creative learning activities in science which are the discovery, understanding, presentation, application and transformation of scientific knowledge.

In addition, teacher's ability to tolerate failure has been suggested as a strategy that can be used to develop creativity. Sternberg \& Lubart (1996) argued that if the school is to impart creativity in students it should have a low tolerance for failure. Intolerance to failure in class makes students afraid to take risks such as trying a new thing or divergent thinking as they would rather conform to the norm to avoid consequences of failure. Amabile (1996) a researcher in the field of social psychology mentioned that the peer group was the main obstacle that caused students not to take risks and express their creative ideas. Torrance (1963) did a longitudinal study and found that students' creativity scores were consistently lower in the fourth year and the cause of the drop in the level of creativity was because pressures to conform to their peer group increased with time.

Inconsistent findings have been discovered on gender differences and creativity. With younger students prior to grade three Kogan (1974) and Tegano and Moran (1989) found a tendency for girls to score higher than boys. However, boys scored higher on originality in grade three. Coone (1969) and Warren and Luria (1972) found higher scores for girls in early adolescence on figural creativity. Likewise, Torrance (1983) found that 
gender differences in divergent thinking ability have changed over time. In the 1950's and 1960's boys outperformed girls on measures of originality, whereas girls surpassed boys on elaboration and most measures of verbal creativity (Torrance, 1962, 1965). Additionally, Bruce (1974) and Torrance, (1963) reported that the gender gap in differences in creativity began to diminish in the 1960's and 1970's. Although divergent thinking is no longer considered to be synonymous with creative ability, it is nevertheless an important component of creative potential (Runco, 1991). A study in Kenya by Ndeke (2003) found that there was a positive and significant relationship between creativity and gender in Biology. Other studies, Okere \& Ndeke (2012), Yuan Z., Wang-Bing S., Chun-Hua S., \& Mei-Cun L. (2017) found that scientific creativity performance of male was significantly better than female for post graduate students. In another study by Shin, J., Jung, H., Choe, S. \& Han, K. (2002) findings indicated that girls, rather than boys, showed better creative performances, demonstrating moderately higher average scores on the three creative measures used in the study.

This study investigated creativity in terms of flexibility, recognition of relationships, sensitivity to a problem and ability to plan for an experiment in chemistry subject for boys and girls. The study also determined the level of students' creativity in chemistry subject.

\subsection{Objective of the Study}

The following were the specific objectives of this study:

1. To determine girls and boys level of scientific creativity in Chemistry

2. To find out whether there are gender differences in scientific creativity in Chemistry

3. To test the relationship between gender and scientific creativity in Chemistry.

4. To derive the hierarchical order on performance on aspects of chemistry scientific creativity

1.2 Hypothesis

In this study, the following null hypothesis was tested;

$\mathrm{H}_{\mathrm{o}} 1$ : $\quad$ There is no statistically significant difference in scientific creativity in Chemistry by gender.

\subsection{Method}

\subsection{Research Design}

The study involved ex-post facto research in which the researcher used causal- comparative and correlational designs. In causal-comparative research variables cannot be manipulated for ethical and practical reasons because the effect of the variable has already occurred (Lodico, Spaulding \& Voegtle, 2006). According to Fraenkel (2006) causal-comparative research is an attempt to identify a causative relationship between an independent variable (in this study gender) and a dependent variable (in this study scientific creativity in Chemistry). In other words investigators attempt to determine the cause or consequences of differences that already exist between or among groups of individuals. Fraenkel (2006) further indicates that the relationship between the independent variable and dependent variable is usually a suggested relationship (not proven) because the researchers do not have complete control over the independent variable. The other key characteristic of causal-comparative research is that individuals are not randomly assigned to groups as the study is involving an event or situation that has already occurred with groups that are already formed (Lodico et al., 2006).

\subsection{Sample and Sampling Procedure}

\subsubsection{The Target Population and Accessible Population}

The target population was all the form three students in all secondary schools in Kenya. The accessible population was Form Three Students in National schools in Nairobi and Kiambu County and Sub-county schools in Muranga and Kajiado counties of Kenya. National schools represent the top cream of academic ability in Kenya. Only those students who pass very well in the Kenya Certificate of Education (KCPE) make it to these prestigious National schools in Kenya. National schools admit high performers from all counties of the republic. These schools admit students with high marks with an average of 400 marks. Sub-county schools on the other hand admit average performers and admission is $100 \%$ of students from the county the schools are situated. Both National and Sub-county schools were used in this study to take care of school characteristic which were intervening variable.

Form Three students were involved in this study because the school administrators are always reluctant to allow the use of Form Four classes since they are an examination class. The Form Three students were appropriate for the study since they had covered enough chemistry content for the purpose of this study. 2.2.2 Sample Size

The guidelines given by Gall, Borg and Gall (1996) were followed in determining the sample size. Where correlation coefficient (r) is used to test hypothesis at 0.05 level of significance a minimum sample of 384 cases is required. When the independent sample t test is used, a minimum sample of 386 is required (Gall, Borg, Gall 1996). Fraenkel, 2006 suggests that if participants are to be grouped large sample size is recommended. In of this, a sample of 672 students was selected for the study. 


\subsection{Instrumentation}

The instrument used in this study was Chemistry Scientific Creativity Test (CSCT). The CSCT had 13 items some (5) formulated by the researcher and some (2) adapted from the Assessment of Performance Unit (A. P. U.) tests. Other questions (6) were adapted from the KNEC examination papers. The Scientific Creativity Test developed by $\mathrm{Hu}$ and Adey was not found appropriate for this study because it was for general science concepts while this study is specific to Scientific Creativity in Chemistry Education. All the items in the CSCT were openended with each question testing different aspect of creativity. The test was aimed at assessing Form Three students' competence in scientific creativity abilities which include; recognition of relationships, flexibility, sensitivity to the problems and planning of investigation in Chemistry. These maps onto the scientific meaning of creativity as shown in Figure 3.

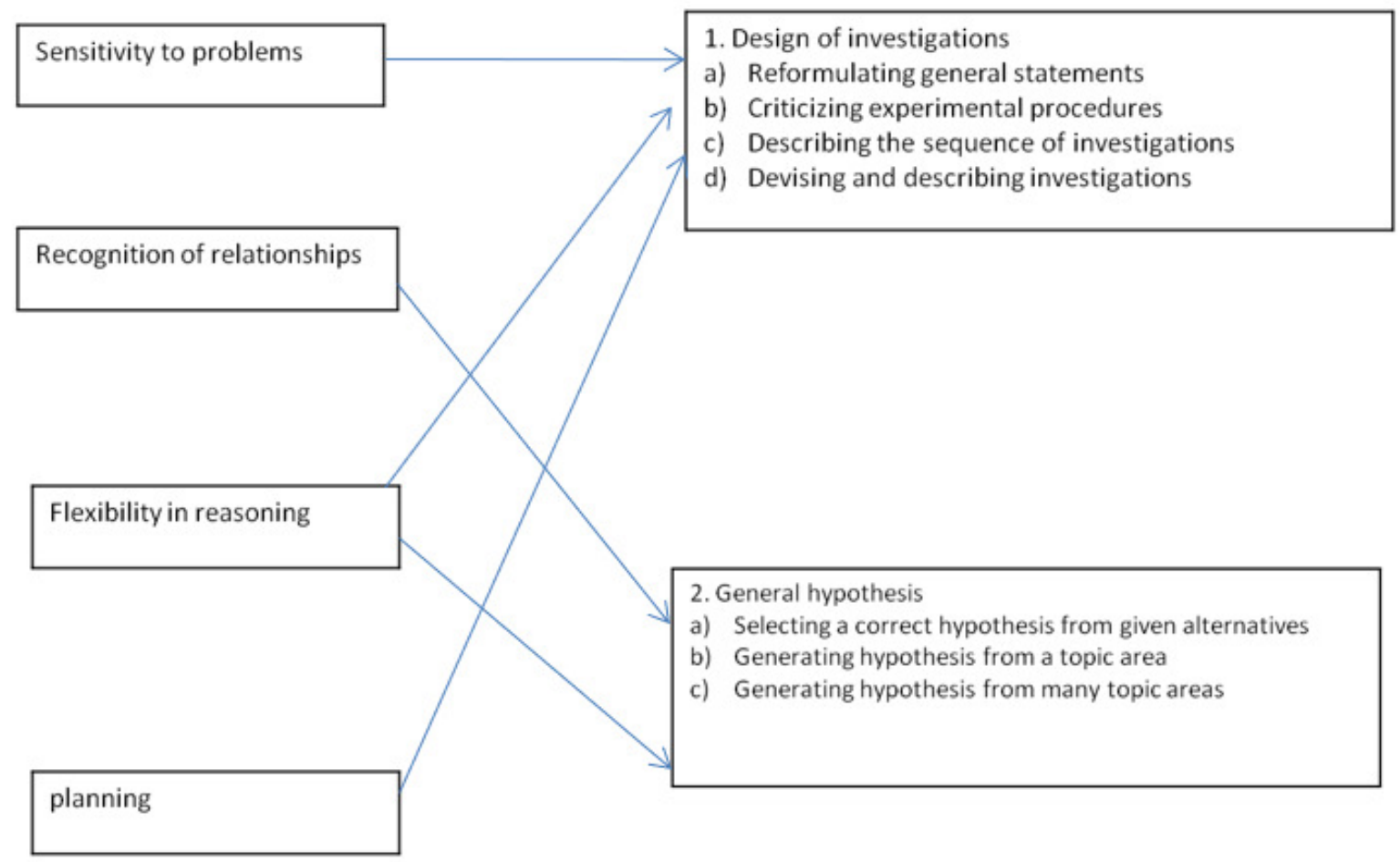

Figure 3: The mapping of psychological definitions of creativity onto scientific meaning (Okere, 1986)

\subsection{Data Analysis and Interpretation}

Data was analysed using inferential statistics. t-test was used to compare the scores of boys and girls in the scientific creativity in Chemistry. Chi-square test was used to test the relationship between gender and scientific creativity. To make reliable inferences from the data, all statistical tests were tested for significance at alpha level at 0.05 .

\subsection{Results}

\subsection{Creativity Level in Chemistry}

Level of creativity in Chemistry was measured by the Chemistry scientific creativity test (CSCT). Learners' raw scores on chemistry creativity test were expressed in percentages. The scores were then categorised into 2 categories high and low with the criterion reference of $40 \%$. Those who scored $40 \%$ and above were categorised as highly creative, while those who scored less than $40 \%$ were categorised as having low scientific creativity. Results of this analysis are show in Table 1.

Table 1. Number and percentage of students and categories of creativity

\begin{tabular}{lcc}
\hline Creativity & Number & $\%$ \\
\hline High & 65 & 9.68 \\
Low & 607 & 90.32 \\
& & \\
Total & 672 & 100.00 \\
\hline
\end{tabular}

Table 1 indicates that the level of scientific creativity in chemistry education is low since only $9.2 \%$ of all the students managed to score $40 \%$ and above in the chemistry scientific creativity test. A score of $40 \%$ and above was categorised as high level of scientific creativity. Majority of the students $90.8 \%$ scored below $40 \%$ which was categorised as a low level of scientific creativity. From this results then it was concluded that the level 
of scientific creativity in chemistry education is low.

These results are in agreement with the findings of Okere and Ndeke (2012) and Hungi (2009) who found out that the level of scientific creativity in Biology were low and findings of Okere (1986) who found that the level of scientific creativity in Physics were low. Similar findings were reported in a study conducted by Siti (2008) which aimed to measure the level of creativity of students in the science program at the Faculty of Education, Universiti Teknologi Malaysia. The study found that a low level of creativity existed for students in the science program at the Faculty of Education. In addition, another related study carried out by Noradilah (2009) to survey whether science students' practice creativity and innovation when implementing the Final Year Project (FYP). Findings showed that there were practices of creativity and innovation during the implementation of FYP, but level of practice was low.

\subsection{Level of Scientific Creativity by Gender.}

Learners' raw scores on chemistry creativity test were expressed in percentages. The scores were then categorised into 2 categories high and low with the criterion reference of $40 \%$. Those who scored $40 \%$ and above were categorised as highly creative, while those who scored less than $40 \%$ were categorised as having low scientific creativity. The scores were also categorised by gender. Results of this analysis are show in Table 2 .

Table 2. Learners categorized scores by level of scientific creativity and gender

\begin{tabular}{|c|c|c|c|c|c|c|}
\hline \multirow[t]{3}{*}{ Creativity Level } & \multicolumn{4}{|c|}{ Gender } & \multirow{2}{*}{\multicolumn{2}{|c|}{ TOTAL }} \\
\hline & \multicolumn{2}{|c|}{ Boys } & \multicolumn{2}{|c|}{ Girls } & & \\
\hline & $\mathbf{N}$ & $\%$ & $\mathbf{N}$ & $\%$ & $\mathbf{N}$ & $\%$ \\
\hline High & 26 & 8.53 & 39 & 9.82 & 65 & 9.12 \\
\hline Low & 249 & 91.48 & 358 & 90.18 & 607 & 90.87 \\
\hline TOTAL & 275 & 100 & 397 & 100.00 & 672 & 100.00 \\
\hline
\end{tabular}

Table 2 indicates that the percentage of girls in the high category of the creativity level is higher $(9.82 \%)$ than that of boys which stands at $8.53 \%$. The total number of students in the high category of creativity is $9.12 \%$ which is lower than the percentage of girls in the high category of chemistry of scientific creativity. It also indicate that $90.87 \%$ of all the students have low level of creativity with a higher percentage of boys $91.48 \%$ having low creativity and $90.18 \%$ of the girls having low creativity level in Chemistry. An in depth analysis to show percentage of categorised scores within creativity and gender was done and results are shown in Table 3 .

Table 3. Learners' percentage of categorized scores by level of scientific creativity and gender

\begin{tabular}{|c|c|c|c|c|c|}
\hline & & & \multicolumn{2}{|c|}{ GENDER } & \multirow[t]{2}{*}{ Total } \\
\hline & & & GIRLS & BOYS & \\
\hline \multirow{8}{*}{$\begin{array}{l}\text { Creativity } \\
\text { categories }\end{array}$} & \multirow{4}{*}{ High } & Number & 39 & 26 & 65 \\
\hline & & $\%$ within Creativity categories & $60.0 \%$ & $40.0 \%$ & $100.0 \%$ \\
\hline & & $\%$ within Gender & $9.8 \%$ & $9.5 \%$ & $9.7 \%$ \\
\hline & & $\%$ of Total & $5.8 \%$ & $3.9 \%$ & $9.7 \%$ \\
\hline & \multirow{4}{*}{ Low } & Number & 358 & 249 & 607 \\
\hline & & $\%$ within Creativity categories & $59.0 \%$ & $41.0 \%$ & $100.0 \%$ \\
\hline & & $\%$ within Gender & $90.2 \%$ & $90.5 \%$ & $90.3 \%$ \\
\hline & & $\%$ of Total & $53.3 \%$ & $37.1 \%$ & $90.3 \%$ \\
\hline
\end{tabular}

Table 3 indicates that $60 \%$ of all the students with the high level of creativity are girls while the remaining $40 \%$ are boys. The percentage of boys with high level of chemistry scientific creativity is $9.5 \%$ which is less than the percentage of girls with high level which is $9.8 \%$. The percentage of both girls and boys in this high level category of scientific creativity is $9.7 \%$. It is also clear from the table that more girls were in the high level of scientific creativity than boys.

To test for the relationship between level of scientific creativity and gender Pearson Chi-square value was computed and the results are represented in Table 4.

Table 4. Relationship between level of scientific creativity and gender

\begin{tabular}{lllcccc}
\hline \multicolumn{7}{c}{ SCIENTIFIC CREATIVITY } \\
\hline SCALE & HIGH & LOW & VALUE & df & p-value \\
\multirow{5}{*}{ Gender } & Girls & 39 & 358 & 0.025 & 1 & 0.874 \\
& Boys & 26 & 249 & & & \\
\hline
\end{tabular}

Results in Table 4, show that 39 girls out of 397, had high level of scientific creativity in chemistry while 26 boys out of 275 boys had high level of scientific creativity. The relation between the two variables was not statistically significant, since chi-square value $\left(\chi^{2}\right)(1, \mathrm{~N}=672)=0.025, \mathrm{p}>0.05$. This indicates that there is no 
significant difference between boys and girls that showed high level and low levels of scientific creativity in Chemistry. This shows that level of scientific creativity is not dependent on gender. The results are in contrast to people's general conception that boys would be more creative than girls.

This results are not in agreement with studies of Okere \& Ndeke (2012), Yuan Z., Wang-Bing S., ChunHua S., \& Mei-Cun L. (2017) which found that scientific creativity performance of male was significantly better than female for post graduate students. In another study by Shin, J., Jung, H., Choe, S. \& Han, K. (2002) found that indicated that girls, rather than boys, showed better creative performances, demonstrating moderately higher average scores on the three creative measures used in the study.

\subsection{Means and Standard Deviation by Gender on the Four Aspects of Scientific Creativity and Overall Scientific Creativity Test}

For the purpose of determining the performance of students by gender in CSCT and in the 4 aspects of scientific creativity, raw scores in the CSCT were used. A number of questions used to compute total scores in;

- Flexibility aspect of scientific creativity 3 questions

- Sensitivity aspect of scientific creativity were 3 questions

- $\quad$ Recognition of relationship were; 7 questions

- $\quad$ Planning aspect 3 questions

All the score in the above questions were used to compute creativity total scores.

The means and standard deviations of each of the four aspects of scientific creativity and the overall scientific creativity are shown in Table 5.

Table 5. Means and standard deviation by gender on all aspects of scientific creativity and overall scientific creativity test

\begin{tabular}{llll}
\hline Aspects of Scientific Creativity & Gender & Mean & Std deviation \\
\hline Flexibility & Girls & 8.06 & 4.24 \\
& Boys & 7.19 & 4.74 \\
Sensitivity & Girls & 3.93 & 2.92 \\
& Boys & 3.58 & 2.53 \\
Planning & Girls & 2.75 & 2.70 \\
& Boys & 2.41 & 3.00 \\
Recognition of Relationship & Girls & 9.25 & 7.82 \\
& Boys & 8.35 & 5.38 \\
Overall Scientific Creativity & Girls & 22.60 & 12.73 \\
& Boys & 20.96 & 13.04 \\
Total Scientific Creativity & & $\mathbf{2 1 . 9 2}$ & $\mathbf{1 2 . 9 3}$ \\
\hline
\end{tabular}

Table 5 confirms that the mean for girls is higher than the mean for boys in all the four aspects of creativity under study. It is also clear that girls scored a higher mean score of $22.60 \%$ in the overall creativity than boys whose mean score was $20.96 \%$. In addition the total scientific creativity in Chemistry for both boys and girls is low, at $21.92 \%$

Planning and sensitivity aspects of scientific creativity had very low mean scores. This could imply that the two aspects are not taught in the classroom. It may even imply that, they are not mentioned or emphasised in the syllabus and even the curriculum hence the poor performance in the CSCT. Flexibility aspect had a higher mean implying that it is taught in the classroom where students are encouraged to generate many responses to a question. However it should be noted that the students were found not very capable of generating many responses in questions that required them to do so. Recognition of the relationship had the highest mean score meaning that this aspect is taught in the classroom. Students were able to recognise relationship of chemistry concepts with what is taught in class (class context) and what happens outside the class (everyday context). It was found out that students were more able to recognise relationships in the class context than in the everyday context.

In a similar study by Ndeke (2012) results indicated that creativity in Biology was gender dependent in favour of boys in flexibility, recognition of relationship and sensitivity aspects of creativity. Planning aspect was not gender dependent.

Table 5 indicates that both boys and girls scored the highest in recognition of relationships, followed by Flexibility, sensitivity and planning got the lowest mean. However the girls scored higher means than boys in all the four aspects of scientific creativity. When the means scored in the four aspects of creativity were arranged in increasing order, a hierarchy in Figure 4 was generated. 


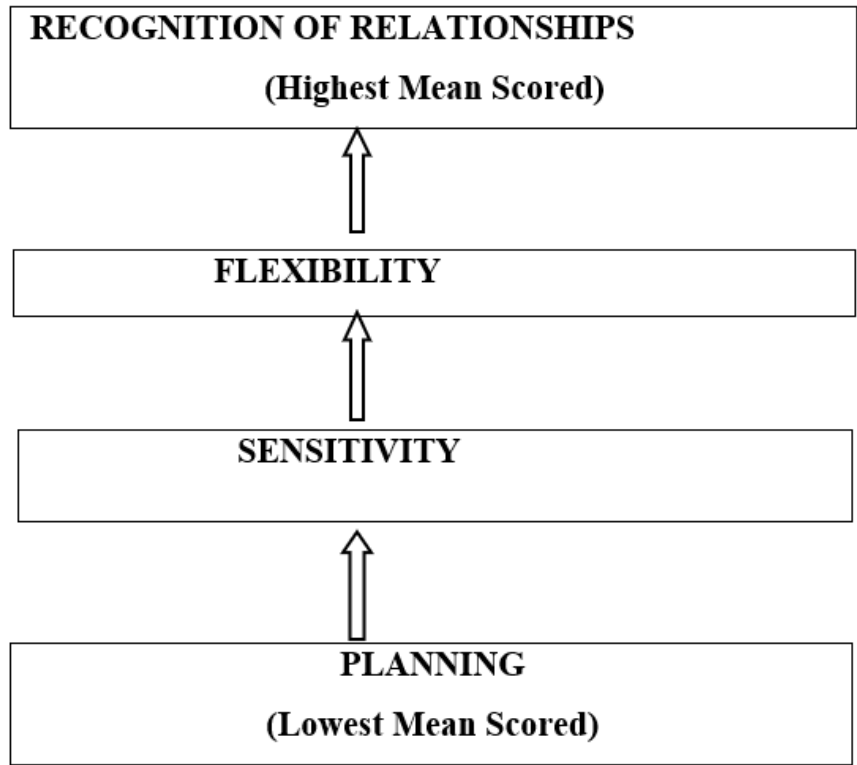

Figure 4: Hierarchical order on performance on aspects of chemistry scientific creativity

Recognition of the relationships aspect of scientific creativity is topmost in the hierarchy meaning it had the highest mean score by both boys and girls implying that it is being enhanced in the classroom. Planning is at the bottom of the hierarchy order suggesting that it was the poorest performed and not enhanced in the classroom. This hierarchy is similar to the one developed in Biology scientific creativity by Ndeke (2002) where Recognition of Relationship was at the top of the hierarchy followed by Flexibility, then Sensitivity and Planning at the bottom of the hierarchy order.

Sensitivity and Planning were poorly performed probably because they are not content dependent. These two aspects of scientific creativity fall under design of investigations in the scientific definitions. According to the current chemistry syllabus the two aspects of creativity are not featured or implied as seen in all the practical lessons learners are not supposed to design investigation procedure but are given the procedures for them to follow. This means the students do not acquire the skill of designing investigation so when they were asked to do so in the CSCT they could not. If students cannot plan investigations then they are unlikely to help solve problems in the society. A similar study done by Okere (1991) on high school students and first year physics undergraduate students on design of scientific experiment produced similar results of students lacking the skill. He attributed this to students either watching teacher demonstration or carrying the practical activities by merely following of the instructions without understanding what they are doing. Table 6 also confirms that the mean for girls is higher than the mean for boys in all the four aspects of creativity under study.

Test of significance (ANOVA - one way) was carried out in order to determine whether or not the differences in attainment between gender and various aspects of creativity were statistically significant. The results of the ANOVA (one way) are displayed in the Table 6.

Table 6. ANOVA (one-way) result of means scores obtained by boys and girls in various aspects of scientific creativity

\begin{tabular}{|c|c|c|c|c|c|c|}
\hline $\begin{array}{l}\text { Aspects of } \\
\text { Creativity }\end{array}$ & Scientific & $\begin{array}{l}\text { Sum of } \\
\text { Squares }\end{array}$ & df & $\begin{array}{l}\text { Mean } \\
\text { Square }\end{array}$ & $\mathbf{F}$ & Sig. \\
\hline \multirow[t]{2}{*}{ Flexibility } & Ssb & 102.17 & 1 & 102.17 & 5.17 & $.023^{*}$ \\
\hline & Ssw & 11230.03 & 569 & 19.74 & & \\
\hline \multirow[t]{2}{*}{ Sensitivity } & $\mathrm{Ssb}$ & 16.16 & 1 & 16.16 & 2.10 & .15 \\
\hline & Ssw & 4403.79 & 572 & 7.70 & & \\
\hline \multirow[t]{2}{*}{ Planning } & $\mathrm{Ssb}$ & 15.718 & 1 & 15.72 & 1.98 & .16 \\
\hline & Ssw & 4547.69 & 572 & 7.95 & & \\
\hline Recognition & $\mathrm{Ssb}$ & 99.72 & 1 & 99.72 & 2.14 & .144 \\
\hline Relationships & Ssw & 23144.54 & 497 & 46.57 & & \\
\hline
\end{tabular}

$\mathrm{Ssb}-$ Sum of squares between; Ssw - Sum of squares within

Table 6 shows that the difference in the means scores of performance in flexibility aspect of scientific creativity of girls and boys were statistically significant at 0.05 level of significance.

This is because the $\mathrm{p}$-value of 0.027 is less than $0.05 . \mathrm{t}(118)=2.221, \mathrm{p}<0.05$. On the other hand the difference in the means scores of performance in sensitivity, planning and recognition of relationships aspects of scientific creativity of girls and boys were not statistically significant at 0.05 level of significance. This is 
because their p-values are greater than 0.05 .

Inconsistent findings have been discovered on gender differences and creativity. With younger students prior to grade three Kogan (1974) and Tegano and Moran (1989) found a tendency for girls to score higher than boys. However, boys scored higher on originality in grade three. Coone (1969) and Warren and Luria (1972) found higher scores for girls in early adolescence on figural creativity. Likewise, Torrance (1983) found that gender differences in divergent thinking ability have changed over time. In the 1950's and 1960's boys outperformed girls on measures of originality, whereas girls surpassed boys on elaboration and most measures of verbal creativity (Torrance, 1962, 1965). Additionally, Bruce (1974) and Torrance, (1963) reported that the gender gap in differences in creativity began to diminish in the 1960's and 1970's.

\subsection{Conclusion}

On the basis of the findings of this study, the researcher made a number of conclusions in relation to the four objectives of the study. These conclusions are:

The level of scientific creativity in chemistry education in Kenyan secondary schools is low. The levels are low in the four of scientific creativity measured in this study namely; Flexibility, sensitivity to a problem, recognition of relationships among variables and planning for investigation. Recognition of relationships had the highest score. There is need to measure scientific creativity in Kenyan primary school pupils and further investigate the causes of the low level in secondary school level.

The scientific creativity in Chemistry is not gender dependent as shown by the difference in scores of the boys and girls being not statistically significantly different. However girls are better than boys in the flexibility aspect of scientific creativity in Chemistry. According to Guilford's divergent thinking abilities 'flexibility' was the number of different types of solutions, therefore girls were able to generate a higher number of responses to a problem than boys. In fact the difference in flexibility was statistically significantly different in favour of girls. The level of creativity in the other three aspects of scientific creativity (sensitivity to a problem, recognition of relationship and planning for experiment is the same for boys and girls.

Of the four aspects of creativity in Chemistry studied, learners scored highly in recognition of relationship followed by flexibility followed by sensitivity to a problem and scored lowest in planning for experiment. Other aspects of creativity in science education should be investigated in primary, secondary and higher education of Kenya education system and in other subject area so as to get a good and clear picture of creativity in Kenya.

Daniel Pink, in his 2005 book A Whole New Mind, repeating arguments posed throughout the 20th century, argued that we are entering a new age where creativity is becoming increasingly important. In this conceptual age, we will need to foster and encourage right-directed thinking (representing creativity and emotion) over leftdirected thinking (representing logical, analytical thought). The present global challenges such as; global economic climate, global warming, youth unemployment, diseases and hunger to mention a few need innovative and creative population that will seek solutions to these problems. So when this study finds out that scientific creativity is low raises pertinent questions on how the $21^{\text {st }}$ century global problems will be solved. There is therefore need for further research to establish why the level are low and strategies that can be used to increase the levels of scientific creativity in all level of education (primary, secondary and higher education).

\section{References}

Adzliana M. D., Jizah O., Punia T. \& Kamisah O. (2012). Creativity in Science Education. Prodecia. Social and Behaviour Science, 59 (2012) 467-474. [Online] Available: htt://www.sciencedirect.com (June 17, 2019)

Aksoy, G. (2005). Create a button science education scientific method process-based learning products, the effect of UNMEE. Zonguldak: Zonguldak Karaelmas University (master's thesis).

Alexander, P. A. (1992). Domain knowledge: Evolving themes and emerging concerns. Educational Psychology, $27,33-51$.

Amabile, T. M. (1987). The motivation to be creative. In S. G. Isaken (ed.) Frontiers of Creativity Research: Beyond the Basics (Buffalo, NY: Bearly) pp. 223-254.

Amabile, T.M. (1996). Creativity in context, update to the social psychology of creativity. Colorado.

Bruce, P. (1974). Reactions of preadolescent girls to science tasks. Journal of Psychology 86(2), 303-308.

Coone, J.G. (1969). A cross-cultural study of sex differences in the development of selected creative thinking abilities (Doctoral dissertation, University of Georgia, 1968). Dissertation Abstracts International, 29, 4828B. [Online] Available: http://www.americanscience.org americansciencej@gm 112 ail.com (June 29, 2014)

Creative Economy Report 2008: (2008). The challenges of assessing the creative economy towards informed policy-making. $\quad$ UNCTAD/DITC/2008/2-20/04/08. [Online] Available: http://www.unctad.org/en/docs/ditc20082cer_en.pdf. (November 10, 2015)

Curriculum Development Centre (2001). Mudul 1: Kamahiran proses Saains. Kementerian Pendidikan Malaysia. Curriculum Development Council. (2002). Science education: Key learning area curriculum guide (primary 1 - 
secondary 3). Hong Kong: Curriculum Development Council

Economy of Culture in Europe, study prepared for the European Commission by KEA, European Affairs, Brussels. (2006). [Online] Available: http://www.keanet.eu/ecoculture/studynew.pdf. (March 8, 2019).

Fraenkel, J. (2006). How to design and evaluate research in education. (pp. 369-395). New York, NY: McGrawHill.

Gall, M.D., Borg, W.R. \& Gall, J. P. (1996). Educational Research: An Introduction. Whiteplains, N, Y: Longman Publisher, USA.

Gilbert, S. W. (1992). Systematic questioning: Taxonomies that develop critical thinking skills. Science Teacher: 59 (9): 41-46.

Guilford, J.P. (1950). Creativity. American Psychologist, 5, 444-454. GUILFORD, J.P. (1967). The nature of human intelligence. New York, NY: McGraw Hill.

Guilford, J.P. (1967). The nature of human intelligence. In J. Freeman et al. (3rd ed) Creativity a Selective of Research. London. Society for research in Higher Education Ltd.

Hungi, S.K. (2009) Influence of Creativity Teaching Strategy on students' Performance and Motivation in topic Energy in Secondary School Physics in Nakuru District. Unpublished Master's Thesis Egerton University.

$\mathrm{Hu}, \mathrm{W} \&$ Adey, P (2002). A scientific creativity test for secondary school Students. International Journal of Science Education, 24, (4), 389-403

Jegede, S. A. (2007). Students' anxiety towards learning of Chemistry in some Nigerian secondary school. Edocational Research Review, 2, 193-197.

Kogan, N. (1974). Creativity and sex differences. Journal of Creative Behaviour, 8(1), 1-14. [Online] Available http://www.americanscience.org americansciencej@gm 112 ail.com

Lodico, M., Spaulding, D., \& Voegtle, K. (2006). Methods in educational research: From theory to practice. San Francisco: Jossey-Bass.

MacKinnon, D. (1970). Creativity: A multi-faceted phenomenon. In J. D. Roslansky (Ed.), Creativity: A Discussion at the Nobel Conference (pp. 17-32). Amsterdam: North-Holland.

McCormack, A. J., \& Yager, R. E. (1989). A new taxonomy of science education. Science Teacher. 56(2): 4748.

Mooney, R. L. (1963). A conceptual model for integrating four approaches to the identification of creative talent. In C. W. Taylor \& F. Barron (Eds.), Scientific Creativity: Its Recognition and Development (pp. 331-340). New York: Wiley.

Ndeke, G.C.W. (2003) "The Effects of Gender, Knowledge and Learning Opportunities on Scientific Creativity amongst Form Three Biology Students. ”Unpublished M.Ed. Thesis. Egerton University.

Noradilah B. S. (2009). Amalan kreativiti dan inovasi melalui projek sarjana muda dalam kalangan pelajar kejuruteraan di UTHM. Tesis sarjana. Universiti Tun Hussein Onn. Malaysia. In Adzliana M. D., Jizah O., Punia T. \& Kamisah O. (2012). Creativity in Science Education. Prodecia. Social and Behaviour Science, 59 (2012) 467-474. [Online] Available: htt://www.sciencedirect.com (June 17, 2019)

Okere, M. I O. (1986) 'Creativity in Physics Education'. Unplished Ph.D. Thesis, University of London.

Okere, M. I O. (1991) 'The Design of scientific Investigation by High School Pupils and First Year Undergraduates.'-East African Journal of Education, 1, 73-83.

Okere, M. I O. (1996) Physics Education: A Textbook of Methods for Physics Teachers. Njoro: Egerton University, Educational Materials Centre \& Lectern Publications.

Okere, M.I.O. \& Ndeke G.C.W (2012). Influence of Gender and Knowledge on Secondary School Students' Scientific Creativity Skills in Nakuru District, Kenya. European Journal of Educational Research 1 (4): 353-366.

Pink, D. H. (2005). A Whole New Mind: Moving from the information age into the conceptual age. Allen \& Unwin.

Runco, M. A. (1991) Divergent Thinking (Norwood, NJ: Ablex).

Runco, M.A. (2004). Creativity. Annual Review of Psychology, 55, 657-687.

Ryhammar, L. \& Brolin, C. (1999). Creativity research: historical considerations and main lines of development. Scandinavian Journal of Educational Research, 43(3), 259-273.

Shin, Ji-Eun \& Jung, Hyun-Chul \& Choe, Seung-Urn \& Han, Ki-Soon. (2002). Are Boys More Creative than Girls? -Based on the Scientific Creativity of Gifted Students-. Journal of the Korean earth science society. 23.

Siti H. B. A. (2008). Tahap kreativiti di kalangan pelajar program sains di fakulti pendidikan, Universiti Teknologi Malaysia. Universiti Teknologi Malaysia (master's thesis). In Adzliana M. D., Jizah O., Punia T. \& Kamisah O. (2012). Creativity in Science Education. Prodecia. Social and Behaviour Science, 59 (2012) 467-474. [Online] Available: htt://www.sciencedirect.com (June 17, 2019)

Sternberg, R.J., \& Lubart, T.I. (1996). Investing in Creativity. American Psychologist. 51 (7): 677-688.

Sternberg, R.J. \& O'hara, L.A. (1999). Creativity and intelligence. In R.J. Sternberg (Ed.) Handbook of creativity 
(pp. 251-272). Cambridge: Cambridge University Press.

Tegano, D.W. \& Moran, J.D. (1989). Sex differences in the original thinking of preschool and elementary school children. Creativity Research Journal, 2(1-2), 102-110.

Torrance, E. P. (1990). The Torrance Tests of Creative Thinking Norms-Technical Manual Figural (streamlined) Forms $A \& B$. Bensenville, IL: Scholastic Testing Service, Inc

Torrance, E. P. (1959). Explorations in Creative Thinking in the Early School Year: VI. Highly Intelligent and Highly Creative Children in a Laboratory School Minneapolis: Bur. Edu. Res. University of Minnesota.

Torrance, E.P (1961). Status of Knowledge Concerning Education and Creativity Scientific Talent. Work Paper for a project on the status of Knowledge about Creative scientific talent, directed by Calvin W, Taylore, University of Utah, with support by the National Science Foundation. In P. E. Vernon (ed) Creativity. Harmondsworth Penguine Book Ltd.

Torrance, E.P (1962). Guiding Creative Talent. In P. E. Vernon (ed). Creativity. Harmondsworth: Penduin.

Torrance, E.P. (1963). Education and the Creative Potential. Minneapolis, MN: University of Minnesota Press. Torrance, E.P. (1965). Rewarding Creative Behaviour. Englewood Cliffs, NJ: Prentice Hall.

Torrance, E.P. (1974). Torrance Tests of Creative Thinking. Personnel Press. Von Franz, Marie-Louise, Psyche and Matter (Shambhala, 1992) ISBN 0-87773-902-1

Torrance, E.P. (1983). Status of Creative Women: Past, Present, and Future. Creative Child and Adult Quarterly, 8(3), 135-144.U.S. Department of Education (1991)

Warren, G.H. \& Luria, Z. (1972). Evaluational Set and Creativity. Perceptual Motor Skills, 1(2), 436-438.

Welsch, P. K. (1981). The nurturance of creative behaviour in educational environments: A comprehensive curriculum approach. Dissertation Abstracts International, 41(09), 3870A (University Microfilms No. 8106456).

Yuan Z., Wang-Bing S. Chun-Hua S. and Mei-Cun L. (2017). The Influence of Gender and Scientific Program Experience on Postgraduates' Creativity. 2017 International Conference on Medical Science and Human Health (MSHH 2017) ISBN: 978-1-60595-1 